\title{
Absence of antimutagenicity of Cochlospermum regium (Mart. and Schr.) Pilger 1924 by micronucleus test in mice
}

\author{
Andrade, LS. a, Santos, DB. ${ }^{\mathrm{a}}$, Castro, DB. ${ }^{\mathrm{a}}$, Guillo, $L A^{\mathrm{b}}$ and Chen-Chen, L. ${ }^{\mathrm{a} *}$ \\ aDepartamento de Biologia Geral, Instituto de Ciências Biológicas, \\ Campus II, Universidade Federal de Goiás, CP 131, CEP 74001-97, Goiânia, GO, Brazil \\ bDepartamento de Bioquímica e Biologia Molecular, Instituto de Ciências Biológicas, \\ Campus II, Universidade Federal de Goiás, Goiânia, GO, Brazil \\ *e-mail:chenlee@icb.ufg.br \\ Received February 20, 2006 - Accepted April 18, 2006 - Distributed February 29, 2008
}

\begin{abstract}
Cochlospermum regium (Mart. and Schr.) Pilger, popularly known as "algodãozinho do campo", is a medicinal plant that grows in the Cerrado of Brazil. This plant has been used in traditional medicine against various diseases such as leucorrhoea, gastritis and ulcers. It has also been effective in treating skin problems like pimples, boils and blotches. In the present study, the in vivo antimutagenicity of aqueous extract of $C$. regium was evaluated. The Micronucleus Test was performed in polychromatic erythrocytes from Swiss male mice treated with one of the four doses of extract of the plant (19, 38, 76 and $114 \mathrm{mg} . \mathrm{kg}^{-1}$ body weight), administered by intraperitonial injection (i.p.) simultaneously with cyclophosphamide (24 mg.kg-1 b.w.) or mitomycin C (4 mg. $\mathrm{kg}^{-1}$ b.w.). The cytotoxicity was evaluated by polychromatic and normochromatic erythrocytes ratio (PCE/NCE). The results showed no significant reduction of the micronucleated polychromatic erythrocytes frequency $(\mathrm{P}>0.05)$. In conclusion, the data indicate that $C$. regium roots aqueous extract, for the conditions used, did not exhibit the antimutagenic effect.
\end{abstract}

Keywords: Cochlospermum regium, antimutagenicity, micronucleus, mice.

\section{Ausência de antimutagenicidade do Cochlospermum regium pelo Teste do Micronúcleo em camundongos}

\begin{abstract}
Resumo
Cochlospermum regium (Mart. \& Schr.) Pilger, conhecido popularmente como “algodãozinho-do-campo", é uma planta medicinal que cresce no Cerrado brasileiro. Esta planta tem sido utilizada na medicina tradicional contra várias doenças como leucorréia, gastrites e úlceras. Esta também tem se mostrado efetiva no tratamento de doenças de pele como espinhas, furúnculos e manchas. No presente estudo, foi avaliada a antimutagenicidade do extrato aquoso de $C$. regium pelo Teste do Micronúcleo in vivo. Este ensaio foi realizado em eritrócitos policromáticos de camundongos machos Swiss tratados com quatro concentrações diferentes do extrato da planta $\left(19,38,76\right.$ e 114 mg. $\mathrm{kg}^{-1}$ por peso corpóreo), administrado por injeção intraperitonial (i.p.) simultaneamente com ciclofosfamida (24 mg.kg-1 p.c.) ou mitomicina C (4 mg.kg-1 p.c.). A citotoxicidade foi avaliada pela razão eritrócitos policromáticos e normocromáticos (PCE/NCE). Os resultados obtidos não mostraram redução significativa da frequiência de eritrócitos policromáticos micronucleados $(\mathrm{P}>0,05)$. Em conclusão, os resultados indicam que o extrato aquoso de raiz de C. regium, para as condições utilizadas, não exibiu efeito antimutagênico.
\end{abstract}

Palavras-chave: Cochlospermum regium, antimutagenicidade, micronúcleo, camundongos.

\section{Introduction}

Plants have always been used as a common source of medicines, both in traditional remedies and in industrialized products. It is estimated that more than $80 \%$ of the world's population use plants as their primary source of medicinal agents (Cordell, 1995). The Brazilian flora has been estimated to be the largest in the world and in this country, plants have always been used for prophylactic effects and for treatment of illness and diseases. Because of this, it is extremely important that the genotoxicity tests of these preparations are made in order to assess their mutagenic potential or modulating of genotoxicity when associated with others substances (Silva et al., 1995; Di Stasi et al., 2002).

In vitro and in vivo studies have shown that some natural constituents of plant parts, such as fruits, leaves and roots play a modulating role in xenobiotic effects (Melo et al., 2001; Ohe et al., 2001; Ren et al., 2001). Identification and characterization of these compounds 
and the definition of their antimutagenic and anticarcinogenic effects can lead to important strategies to reduce the risk of developing cancer in human beings (Dearfield et al., 2002). Several studies have reported the antimutagenic effect of plant aqueous extracts (Aruoma, 2003; Carréon et al., 2002). In this sense, some medicinal plant teas popularly used have been investigated for mutagenicity and antimutagenicity mechanisms (Brockman et al., 1992; Mendelsohn, 1992; Peryt et al., 1992).

Cochlospermum regium (Mart. and Schr.) Pilger (Cochlospermaceae), popularly known as "algodãozinho-do-campo" is a plant native of the "Cerrado". This plant has been reputed to have antiinflammatory, analgesic, antiedematogenic and antibacterial properties and has been employed extensively in popular medicine for treatments of gastritis, ulcers, for skin removal and other diseases (Correa, 1975; Siqueira et al., 1994; Oliveira et al., 1996). It has already been reported that roots of Cochlospermum regium contain triterpenoids compounds, flavonoids, saponines, tannins and phenolic compounds (Ritto, 1996). In earlier study, it was reported that the flavonoid 3-0-glicosildihidrocanferol, isolated from Cochlospermum regium roots extract, exhibited antinociceptive effect (Castro, 2000). It has also been shown the acute and subacute toxicity of roots hydroethanol extract of this plant in mice and rats (Toledo et al., 2000) besides antibacterial activity of this essential oil (Brum et al., 1997). Recently, Ceschini and Campos (2006) have detected the cytotoxic activity of $C$. regium extract against non-tumorigenic $\mathrm{CHO}-\mathrm{K} 1$ cells by inhibition cell proliferation and induction of apoptosis.

In relation to genotoxicity study, Nunes and Carvalho (2003) did not detect genotoxic activity of the C. regium roots aqueous extract in Drosophila melanogaster Meigen, 1830 germinative cells but this extract has provoked mutations and recombinations in somatic cells. Recent investigations in our laboratory have indicated that the i.p. administration of the aqueous extract of this same plant showed mutagenic effect in mice bone marrow. We have suggested that the mutagenic activity of $C$. regium could be associated to the action of chemical constituents of this plant (Castro et al., 2004). It is well established that many substances reported to be mutagens or carcinogens have themselves, been shown to be antimutagenic or anticarcinogenic (Zeiger, 2003). In this sense, in the present work, we aimed to evaluate the antimutagenic activity of the roots extract of $C$. regium by mouse bone marrow micronucleus test. We have utilized two known mutagens, a direct alkylating agent (MMC) and an indirect cytostatic compound (CP) to evaluate the antimutagenic effect of the C. regium roots aqueous extract.

\section{Materials and Methods}

\subsection{Plant material}

The roots of Cochlospermum regium were collected in Silvânia, Goiás State, Brazil, in June 1999. A voucher specimen was deposited at the Herbarium of the Federal
University of Goiás under number 22522/UFG. The roots of this plant were dried at $45{ }^{\circ} \mathrm{C}$ in a forced ventilation stove and ground in a fraction mill to a dry powder that was submitted by the hot aqueous extraction process and later lyophilization. The lyophilized extract was stored at $4{ }^{\circ} \mathrm{C}$ until further use. Tests were done with the total lyophilized extract dissolved in water just before use.

\subsection{Animals}

Male Swiss albino mice were obtained from Central Biotery of Federal University of Goiás (Goiás, Brazil). They were 8-12 week-old and housed in plastic cages with a bedding of wood shavings. Animals weighed $35 \pm 10 \mathrm{~g}$ at the start of the study. They were housed in an air-conditioned room $\left(24 \pm 2{ }^{\circ} \mathrm{C} ; 55 \pm 5 \%\right.$ relative humidity) with a 12 hours light-dark cycle, and had free access to drinking water and food (Albina, Ecibra Ltda).

\subsection{Chemical and drugs}

Mitomycin C, acquired from Bristol-Myers Squibb, and Cyclophosphamide, obtained from Sigma-Aldrich Chemical Company, were used in the evaluation of antimutagenicity of extract of $C$. regium.

Giemsa was obtained from Doles Reagentes e Equipamentos para Laboratórios in Goiânia, Goiás. Methanol was obtained from Labsynth Produtos para Laboratórios and fetal calf serum from Laborclin Produtos para Laboratórios. Others chemicals, dibasic sodium phosphate and monobasic sodium phosphate was purchased from Sigma-Aldrich Chemical Company.

\subsection{Experimental design}

Doses of $C$. regium extract roots $(19,38,76$ and $114 \mathrm{mg} \cdot \mathrm{kg}^{-1}$ body weight) and mitomycin C (MMC) (4 $\mathrm{mg} . \mathrm{kg}^{-1}$ ) were administered simultaneously by intraperitonial injection (i.p.) in groups of five animals for each treatment. These doses were selected according to the $\mathrm{LD}_{50}$ (single dose 15-day i.p. LD50) (Ritto et al., 1996) of $C$. regium extract $\left(10,20,40\right.$ and $60 \%$ of $\mathrm{LD}_{50}$, respectively). The positive controls, MMC (4 mg. $\left.\mathrm{kg}^{-1}\right)$ and $\mathrm{CP}\left(24 \mathrm{mg} \cdot \mathrm{kg}^{-1}\right)$, and negative control (distilled and sterilized water) were also included. Mice were killed by cervical dislocation 24 hours after administration, femurs were dissected, opened and the bone marrow was gently flushed out fetal calf serum. After centrifugation (300x g, 5 minutes), the bone marrow cells were smeared on glass slides, coded for blind analysis, air-dried and fixed with absolute methanol for five minutes. The smears were fixed with Giemsa for detecting micronucleated polychromatic erythrocytes (MNPCE) frequency. For each mouse, two slides were prepared and 1000 polychromatic erythrocytes (PCE) per slide were scored to determine the frequency of MNPCE. The results were the average of the two slides. The same methodology was applied using the same doses of $C$. regium extract plus cyclophosphamide (CP) (24 mg. $\left.\mathrm{kg}^{-1}\right)$ i.p. also in groups of five animals. To determine the cytotoxic activity, 1000 normochromatic erythrocytes were computed and simulta- 
neously were computed the polychromatic erythrocytes frequency.

\subsection{Statistical analysis}

In order to analyze the antimutagenic activity of the roots of $C$. regium, the frequency of the MNPCE from the treated groups were compared to the results obtained from the positive control groups by Student's $t$-test. The same results were also compared to the negative control group by the $t$-test. $\mathrm{P}$ values less than $0.05(\mathrm{P}<0.05)$ were considered as indicative of significance. To evaluate the cytotoxic action, the PCE/NCE ratio with different concentrations extract was compared to positive controls (MMC and $\mathrm{CP}$ ) by qui-square test $\left(\chi^{2}\right) . \mathrm{P}$ values less than 0.05 $(\mathrm{P}<0.05)$ were considered as indicative of significance.

\section{Results}

The results obtained from the mouse bone marrow cells after 24 hours of administration with extract of $C$. regium plus MMC and extract of $C$. regium plus $\mathrm{CP}$ are shown in Table 1. The MNPCE means (per 1000 PCE) in the mice were $16.8,17.2,17.6$ and 18.8 in the groups exposed to treatment of 19, 38, 76 and $114 \mathrm{mg} \cdot \mathrm{kg}^{-1}$ body weight (b.w.) of plant extract plus MMC (4 mg. $\mathrm{kg}^{-1}$ b.w.) respectively, while that of the positive control was 19.6. Thus, no significantly reduction of MMC-induced micronuclei was observed $(\mathrm{P}>0.05)$. The group that received 19, 38, 76 and $114 \mathrm{mg} . \mathrm{kg}^{-1}$ b.w. of plant extract plus CP (24 mg.kgb.w.) showed a mean of 18.0, 18.6, 18.8 and 19.2 MNPCE (per $1000 \mathrm{PCE}$ ) respectively, while that of the positive control was 18.8. In this manner, the plant extract showed no inhibition of CP-induced micronuclei by $C$. regium extract $(\mathrm{P}>0.05)$. All treatments with plant extract plus MMC or $\mathrm{CP}$ exhibited significant difference compared to the nega- tive control group $(\mathrm{P}<0.05)$. The simultaneous treatment of the $C$. regium roots extract and $\mathrm{MMC}$ or $\mathrm{CP}$ did not alter significantly the $\mathrm{PCE} / \mathrm{NCE}$ ratio when compared to positive controls $(\mathrm{P}>0.05)$. The $\mathrm{PCE} / \mathrm{NCE}$ ratio was 0.34 , $0.32,0.34$ and 0.32 in groups exposed to treatment of 19 , 38, 76 and 114 mg.kg ${ }^{-1}$ b.w. of plant extract plus MMC, respectively, while the positive control was 0.31 . Thus, simultaneous treatment of the $C$. regium extract and MMC did not alter the PCE/NCE ratio when compared with the positive control (MMC) $(\mathrm{P}>0.05)$. The $\mathrm{PCE} / \mathrm{NCE}$ ratio was $0.38,0.38,0.37$ and 0.36 in groups exposed to treatment of 19, 38, 76 and $114 \mathrm{mg} \cdot \mathrm{kg}^{-1}$ b.w. of plant extract plus CP, respectively, while the positive control was 0.39 (CP). Thus, simultaneous treatment of the $C$. regium extract and $\mathrm{CP}$ also did not alter PCE/NCE ratio when compared to positive control $(\mathrm{CP})(\mathrm{P}>0.05)$.

\section{Discussion}

The present study was conducted in order to evaluate the antimutagenicity of the extract of rhizome of Cochlospermum regium on mice bone marrow cells. Intraperitoneal treatment was chosen because it maximizes the absorption and penetration of target cells (Preston et al., 1981). The micronuclei in young erythrocytes arise primarily from chromosome fragments that are not incorporated into the daughter nuclei at the time of cell division in the erythropoietic bast cells and changes in the incidence of MNPCE are considered to reflect chromosomal damage (Salamone and Heddle, 1983). Chromosomal aberrations are known to be important somatic mutations and are clearly involved in the origin, progression and diversification of certain cancers (Povirk and Shuker, 1994).

Table 1. Frequencies of micronucleated polychromatic erythrocytes in bone marrow of mice treated with extract of rhizome of $C$. regium plus mitomycin $\mathrm{C}$ and cyclophosphamide.

\begin{tabular}{|c|c|c|c|c|c|c|}
\hline \multirow[t]{2}{*}{ Treatment } & \multirow{2}{*}{$\begin{array}{c}\text { No. of } \\
\text { Animals }\end{array}$} & \multicolumn{4}{|c|}{ Micronucleated polychromatic erythrocytes } & \multirow[t]{2}{*}{ EPC/ ENC } \\
\hline & & Individual data $^{\mathrm{a}}$ & No. & $\%$ & Mean \pm SD $^{\mathrm{a}}$ & \\
\hline Water (negative control) & 05 & $03,01,01,03,02$ & 10 & 0.20 & $2.0 \pm 0.10$ & 0.96 \\
\hline MMC (positive control) & 05 & $18,19,22,16,23$ & 98 & 1.96 & $19.6^{\mathrm{b}} \pm 2.88$ & 0.31 \\
\hline $\mathrm{CP}$ (positive control) & 05 & $19,22,16,23,14$ & 94 & 1.88 & $18.8^{\mathrm{b}} \pm 3.83$ & 0.39 \\
\hline \multicolumn{7}{|l|}{ Extract + MMC } \\
\hline $19 \mathrm{mg} \cdot \mathrm{kg}^{-1}$ & 05 & $20,17.5,16,18.5,12$ & 84 & 1.68 & $16.8^{\mathrm{b}, \mathrm{c}} \pm 3.05$ & 0.34 \\
\hline $38 \mathrm{mg} \cdot \mathrm{kg}^{-1}$ & 05 & $23,17,17.5,13,15.5$ & 86 & 1.72 & $17.2^{\mathrm{b}, \mathrm{c}} \pm 3.68$ & 0.32 \\
\hline $76 \mathrm{mg} \cdot \mathrm{kg}^{-1}$ & 05 & $21,19,17,18,13$ & 88 & 1.76 & $17.6^{\mathrm{b}, \mathrm{c}} \pm 2.96$ & 0.34 \\
\hline $114 \mathrm{mg} \cdot \mathrm{kg}^{-1}$ & 05 & $17,18.5,14,24,20.5$ & 94 & 1.88 & $18.8^{b, c} \pm 3.75$ & 0.32 \\
\hline \multicolumn{7}{|l|}{ Extract $+\mathrm{CP}$} \\
\hline $19 \mathrm{mg} \cdot \mathrm{kg}^{-1}$ & 05 & $17,13,20,24,16$ & 90 & 1.80 & $18.0^{\mathrm{b}, \mathrm{c}} \pm 4.18$ & 0.38 \\
\hline $38 \mathrm{mg} \cdot \mathrm{kg}^{-1}$ & 05 & $16,23,21,13,20$ & 93 & 1.86 & $18.6^{\mathrm{b}, \mathrm{c}} \pm 4.03$ & 0.38 \\
\hline $76 \mathrm{mg} \cdot \mathrm{kg}^{-1}$ & 05 & $22,19,21.5,15,16.5$ & 94 & 1.88 & $18.8^{\mathrm{b}, \mathrm{c}} \pm 3.05$ & 0.37 \\
\hline $114 \mathrm{mg} \cdot \mathrm{kg}^{-1}$ & 05 & $18,15,20,23,20$ & 96 & 1.92 & $19.2^{\mathrm{b}, \mathrm{c}} \pm 2.94$ & 0.36 \\
\hline
\end{tabular}

aPer 1000 polychromatic erythrocytes per mouse.

${ }^{\mathrm{b}}$ Statistically different from the negative control ( $\mathrm{H}_{2} \mathrm{O}$ distilled). $* \mathrm{P}<0.05$.

${ }^{\mathrm{c}}$ No statistically different from the positive control; ${ }^{2} \mathrm{P}>0.05$.

MMC, mitomycin C (4 mg. $\mathrm{kg}^{-1}$ body weight); CP, cyclophosphamide (24 mg. $\mathrm{kg}^{-1}$ body weight). 
Table 2. Frequencies of micronucleated polychromatic erythrocytes in bone marrow of mice treated with extract of rhizome of $C$. regium

\begin{tabular}{|c|c|c|c|c|c|c|}
\hline \multirow[t]{2}{*}{ Treatment } & \multirow{2}{*}{$\begin{array}{c}\text { No. of } \\
\text { Animals }\end{array}$} & \multicolumn{4}{|c|}{ Micronucleated polychromatic erythrocytes } & \multirow[t]{2}{*}{ EPC/ ENC } \\
\hline & & Individual data ${ }^{\mathrm{a}}$ & No. & $\%$ & Mean \pm SD $^{\mathbf{a}}$ & \\
\hline Water (negative control) & 05 & $03,01,01,03,02$ & 10 & 0.20 & $2.00 \pm 0.10$ & 0.96 \\
\hline MMC (positive control) & 05 & $18,19,22,16,23$ & 98 & 1.96 & $19.6^{\mathrm{b}} \pm 2.88$ & 0.31 \\
\hline \multicolumn{7}{|l|}{ Extract } \\
\hline $19 \mathrm{mg} \cdot \mathrm{kg}^{-1}$ & 05 & $04,01,04,03,03$ & 15 & 0.30 & $3.0 \pm 1.22$ & 0.85 \\
\hline $38 \mathrm{mg} \cdot \mathrm{kg}^{-1}$ & 05 & $07,05,04,03,05$ & 24 & 0.48 & $4.8^{\mathrm{b}} \pm 1.48$ & 0.77 \\
\hline $76 \mathrm{mg} \cdot \mathrm{kg}^{-1}$ & 05 & $07,11,07,09,06$ & 40 & 0.80 & $8.0^{\mathrm{b}} \pm 2.00$ & 0.72 \\
\hline 114 mg.kg ${ }^{-1}$ & 05 & $15,11,17,11,14$ & 68 & 1.36 & $13.6^{\mathrm{b}} \pm 2.61$ & 0.65 \\
\hline
\end{tabular}

${ }^{\text {aPer }} 1000$ polychromatic erythrocytes per mouse.

${ }^{\mathrm{b}}$ Statistically different from the negative control ( $\mathrm{H}_{2} \mathrm{O}$ distilled).

MMC, mitomycin C (4 mg.kg-1 body weight).

In earlier work conducted in our laboratory, we evaluated the potential of micronuclei induction of $C$. regium in mice Swiss (Castro et al., 2004). These results are shown in Table 2. The obtained results have showed that the aqueous extract of the $C$. regium exhibited significant micronuclei induction in the three higher doses when compared with negative control.

Although other studies have reported on the antimutagenicity of some compounds of this plant, like tannins (Imanishi et al., 1991; Weisburger et al., 1996; Kaur et al., 1998; Mejía et al., 1999) and flavonoids (Wall et al., 1988; Edenharder et al., 1997), we did not find a protective effect of aqueous extract of $C$. regium roots against $\mathrm{CP}$ and MMC-induced DNA damage. The fact that some inhibitors induce adverse effects depends on various factors. Some inhibitors stimulate, in certain instances, enhancing and detoxifying mechanisms, many antioxidants can depending on the redox potential, either accept or donate electrons, which may alternatively render them either protective or noxious (Stich and Rosin, 1984; Collins, 2001).

In summary, roots aqueous extract of $C$. regium did not reduce the occurrence of $\mathrm{MMC}$ and $\mathrm{CP}$-induced micronuclei in mice bone marrow, suggesting no antimutagenic effect of this plant in our experimental conditions.

Acknowledgments - The authors are grateful to Pedro Henrique Ferri and Suzana da Costa Santos for extraction and lyophilization of plant material. This work was supported by Conselho Nacional de Desenvolvimento Científico e Tecnológico (CNPq) and Fundação de Apoio à Pesquisa (FUNAPE).

\section{References}

ARUOMA, O., 2003. Methodological considerations for characterizing potential antioxidant actions of bioactive components in plant foods. Mutat. Res., vol. 523-524, p. 9-20.

BROCKMAN, HE., STACK, HF. and WATERS, MD., 1992. Antimutagenicity profiles of some natural substances. Mutat. Res., vol. 267, no. 2, p. 157-172.
BRUM, RL., HONDA, NK., HESS, SC., CRUZ, AB. and MORETTO, E., 1997. Antibacterial activity of Cochlospermum regium essential oil. Fitoterapia, vol. 68, no. 1, p. 79.

CARRÉON, JIP., JIMÉNEZ, GC., VEJA, JAL., POPOCA, EA., FAZENDA, SF. and TREVIÑO, SV., 2002. Genotoxic and antigenotoxic properties of Calendula officinalis extracts in rat liver cell cultures treated with diethylnitrosamine. Toxicol. In Vitro, vol. 16, n. 3, p. 253-258.

CASTRO, DB., SANTOS, DB., FERREIRA, HD., SANTOS, SC. and CHEN-CHEN, L., 2004. Atividades Mutagênica e Citotóxica do Extrato de Cochlospermum regium Mart. (algodãozinho-do-campo) em camundongos. Rev. Bras. Pl. Med., vol. 6, suppl. 3, p. 15-19.

CASTRO, MSA., 2000. Mecanismos envolvidos no efeito antinociceptivo do 3-0-glicosildihidrocanferol, flavonóide extraído dos rizomas de Cochlospermum regium (algodãozinho). Tese de Doutorado. Universidade de São Paulo, São Paulo.

CESCHINI, L. and CAMPOS, EG., 2006. Cytotoxic effects of Cochlospermum regium (Mart and Schrank) Pilger aqueous root extract on mammalian cells. J. Ethnopharmacol., vol. 103, no. 2 , p. 302-305.

COLLINS, AR., 2001. Carotenoids and genomic stability. Mutat. Res., vol. 475, no. 1-2, p. 21-28.

CORDELL, GA., 1995. Changing strategies in natural products chemistry. Phytochemistry, vol. 40, no. 6, p. 1585-1612.

CORREA, MP., 1975. Dicionário das plantas úteis do Brasil e das exóticas cultivadas, p. 747. Imprensa Nacional (Ministério da Agricultura, Ind. e Comércio), Rio de Janeiro, vol. 6, 777 p.

DEARFIELD, KL., CIMINO, MC., MCCARROLL, NE., MAUER, I. and VALCOVIC, LR., 2002. Genotoxicity risk assessment: a proposed classification strategy. Mutat. Res., vol. 521, no. 1-2, p. 121-135.

DI STASI, LC., OLIVEIRA, GP., CARVALHAES, MA., QUEIROZ-JUNIOR, M., TIEN, OS., KAKINAMI, SH. and REIS, MS., 2002. Medicinal plants popularly used in the Brazilian Tropical Atlantic Forest. Fitoterapia, vol. 73, no. 1, p. 69-91.

EDENHARDER, R., RAUSCHER, R., and PLATT, KL., 1997. The inhibition by flavonoids of 2-amino-3-methylimidazo [4,5- $f]$ quinoline metabolic activation to a mutagen: a structure-activity relationship study. Mutat. Res., vol. 379, no. 1, p. 21-32. 
IMANISHI, H., SASAKI, YF., OHTA, T., WATANABE, M., KATE, T. and SHIRASU,Y., 1991. Tea tannin components modify the induction of sister-chromatid exchanges and chromosome aberrations in mutagen-treated cultured mammalian cells and mice. Mutat. Res., vol. 259, no. 1, p. 79-87.

KAUR, S., GROVER, IS., SINGH, M. and KAUR, S., 1998. Antimutagenicity of hydrolysable tannins from Terminalia chebula in Salmonella typhimurium. Mutat. Res., vol. 419, no. 1-3, p. 169-179.

MEJÍA, EG., TOSTADO, EC. and PIÑA, GL., 1999. Antimutagenic effects of natural phenolic compounds in beans. Mutat. Res., vol. 441, no. 1, p. 1-9.

MELO, SF., SOARES, SF., COSTA, RF., SILVA, CR., OLIVEIRA, MB., BEZERRA, RJ., ARAÚJO, AC. and BERNARDO-FILHO, M., 2001. Effect of the Cymbopogon citratus, Maytenus ilicifolia and Baccharis genistelloides extracts against the stannous chloride oxidative damage in Escherichia coli. Mutat. Res., vol. 496, no. 1-2, p. 33-38.

MENDELSOHN, ML., 1992. Antimutagenic effects in humans. Mutat. Res., vol. 267, no. 2, p. 57-264.

NUNES, WB. and CARVALHO, S., 2003. Evaluation of the mutagenic potential of Cochlospermum regium in Drosophila melanogaster male germ cells. Genet. Mol. Biol., vol. 26, no. 4, p. 545-549.

OHE, T., MARUTANI, K. and NAKASE, S., 2001. Catechins are not major components responsible for anti-genotoxic effects of tea extracts against nitroarenes. Mutat. Res., vol. 496, no. 1-2, p. $75-81$.

OLIVEIRA, CC., SIQUEIRA, JM., SOUZA, KCB. and RESENDE, UM., 1996. Antibacterial activity of rhizomes from Cochlospermum regium: preliminary results. Fitoterapia, vol. 67 , no. 2 , p. 176-177.

PERYT, B., SZYMCZYK, T. and LESCA, P., 1992. Mechanism of antimutagenicity of wheat sprout extracts. Mutat. Res., vol. 269 , no. 2 , p. 201-215.

POVIRK, LF. and SHUKER, DE., 1994. DNA damage mutagenesis induced by nitrogen mustards. Mutat. Res., vol. 318 , no. 3, p. 205-226.

PRESTON, RJ., AU, W., BENDER, MA., BREWEN, JG., CARRANO, AV., HEDDLE, JA., MACFEE, AF., WOLFF, S. and WASSON, JS., 1981. Mammalian in vivo and in vitro cytogenetic assays, a report of the US. EPA's Gene-Tox Program. Mutat. Res., vol. 87, no. 2, p. 143-188.
REN, H., ENDO, H. and HAYASHI, T., 2001. The superiority of organically cultivated vegetables to general ones regarding antimutagenic activities. Mutat. Res., vol. 496, no. 1-2, p. 83-88.

RITTO, JLA., 1996. Caracterização farmacognóstica da droga e do extrato fluido de algodãozinho-do-campo, $a$ Cochlospermum regium (MART et SCHR.) PILGER. Dissertação de Mestrado. Universidade de São Paulo, São Paulo.

SALAMONE, MF. and HEDDLE, JA., 1983. The bone marrow micronucleus assay: Rationale for a revised protocol. In SERRES, FJ. (ed.), Chemical Mutagen: Principles and Methods for their Detection, Plenum Press, Amsterdam, vol. 8, p. 111-149.

SILVA, I., FRANCO, SL., MOLINARI, SL., CONEGERO, CI., MIRANDA NETO, MH., CARDOSO, MLC., SANTANA, DMG. and IWANKO, NS., 1995. Noções sobre o organismo humano e utilizações de plantas medicinais, Assoeste-Editora Educativa, Cascavel. p. 203.

SIQUEIRA, JM., CASTRO, MSA., MELLO, JCP., KASSAB, NM., VIEIRA, ICP., AMORIM, LWK., GUERRA, MC. and RESENDE, UM., 1994. Flavanona do extrato hidroalcoólico de Cochlospermum regium (MART. and $\mathrm{SCH}$.) Pilger (algodãozinho-do-campo). Simpósio de Plantas Medicinais do Brasil, Fortaleza.

STICH, HF. and ROSIN, MP., 1984. Nutritional and Toxicological Aspects of Food Safety. Adv. Exp. Med. Biol., vol. 177, p. 1-584.

TOLEDO, MI., SIQUEIRA, JM., ARAÚJO, LCL. and OGA, S., 2000. Acute and subacute toxicity of Cochlospermum regium (MART. and SCHR.) Pilger. Phytother. Res., vol. 14, no. 5 , p. 359-361.

WALL, ME., WANI, MC., MANIKUMAR, G., ABRAHAM, P., TAYLOR, H., HUGHES, TJ., WARNER, J., MCGIVNEY, R., 1988. Plant antimutagenic agents, 2. Flavonoids. J. Nat. Prod., vol. 51, no. 6, p. 1084-1091.

WEISBURGER, JH., HARA, Y., DOLAN, L., LUO, FQ., PITTMAN, B., ZANG, E., 1996. Tea polyphenols as inhibitors of mutagenicity of major classes of carcinogens. Mutat. Res., vol. 371 , no. $1-2$., p. 57-63.

ZEIGER, E., 2003. Illusions of safety: antimutagens can be mutagens, and anticarcinogens can be carcinogens. Mutat. Res., vol. 543, no. 3, p. 191-194. 
